\title{
ALTERNATIVE MEASURE IN PROVIDING REAL ESTATE INFRASTRUCTURE IN A RECESS ECONOMY IN AWKA, ANAMBRA STATE NIGERIA
}

\author{
Emenike Kingsley Chikwuado, \\ Department Of Estate Management and Valuation Faculty of Environmental science, University of Uyo, \\ Uyo, Akwa-Ibom State. Nigeria West Africa
}

\begin{abstract}
Alternative measure in providing real infrastructure is a process that aims at providing facilities that help the smooth running of an estate without depending on the government solely, by integration of different stake holders mutually providing those facilities through certain modalities and responsibilities to enhance efficiency that will benefit our national economy on the long run. Deficit in real estate infrastructure has a tremendous effect on our national economy and development. The purpose of this study was to search for a better alternative in terms of legislation, policy, procedure and implementation that will produce substantial result in providing real estate infrastructure. The study is to be executed through primary and secondary data sources. First, real estate infrastructure company's transaction details were obtained primarily for this study; we consulted few estates and land-lord association for primary data collection and all the relevant stake holders. Secondly, secondary data was sourced from text books, journals and newsletters. The collected data were analyzed using spss international business machine software, our results, finding and conclusion was aimed at finding an alternative in providing real estate infrastructure.
\end{abstract}

Keywords: Alternative, Real Estate, Infrastructure, Economy.

\section{INTRODUCTION}

Real estate infrastructure is the paramount factor for development since real estate development is one of the fastest safest investments in the world as it provides investors a wide range of benefit which includes profit, prestige, collateral from bank facility etc.
Real estate infrastructure is capital intensive in nature, they require considerable amount of capital to install, construct and provide them. Hence, only a very small percentage of the infrastructure is normally provide by individual investors it is therefore vital for investors and the society in general to have basic knowledge on alternative measure to provide some basic infrastructure with little or no government intervention.

The huge capital requirement/cost for real estate infrastructure have discourage quite a number of investors, while the bold and un-wavering lot have found wisdom in seeking professional advice and preparation of detailed viability reports in other to maximize opportunity in providing these infrastructure.

The estate surveyor and valuer usually after professional advice to enlightened investors as regards the best investment option in real estate development since the provision of infrastructure will attract higher returns on the investment.

The estate surveyor and valuers champions the business of land acquisition of plotting of land development, maintenance and coordinate other maintenance personnel particularly the engineering personnel. It would be an appreciation to land and landed property if adequate infrastructure is provided. [1] Ozigbo and Ozigbo(2013),

\section{LITERATURE REVIEW}

Real estate infrastructure in the recent time has proven to be among the key factors in the success of real estate sector; hence it reveals the latent values of land and landed property. The supply of these infrastructures can create a constructive revolution in real estate sector. 
The concept of real estate infrastructure is the understanding of the term real estate infrastructure requires distinction between real estate and infrastructure. These terms goes in pari-per sue but that notwithstanding, it is vital to examine the discrepancy in their meaning. According to [2] (Iloba, 2009) ,[3] (Stapleton, 1986) and [4] (Thorncroft, 1965) the term real estate is broad and very wide to explain. it encompasses the "Physical Identity"[5] Igbinosa (2011),[6] Joslin(2005),[7] Kauko(2003),[8] Olusegun(2003),[9] Onyebanji(2003),[10](punch,2013)

"Economic Identity”[11] (Karol,2010), [12] Board (2016), [13] Golob,Bastic and Psunder,(2012), "Legal Identity" [14] Dadem (2009), [15] Drummond, (1955), “Management Character"[16] Ariyawansa (2009),

[17] Udechukwu,Olusola (2008), [18] Scarret (1995). From the above opinion one will understand that the definition of estate is very wide in scope, in a nut shell estate is an interest that exist over land and landed property or defined an estate as a wide term, but include an interest in land and landed property or an asset which is capable of conferring on the possessor or his beneficiaries. While infrastructure on the other hand represents facilities and services that are developed by government, private or public institution to enhance efficient functioning of urban economy

[19] Udoudoh and Ofem(2017). Infrastructure network is the very socio-economic climate created by the institutions (public or private) that serve as conduits of trade and investment. The role of infrastructure in the context of integration is transformative, through enhancing change of resources into outputs or enhancing trade by removing barriers. An improvement in a country's infrastructure is one of the key factors affecting the long term growth of such a country. [21]" Ajibola et al,( 2010) opined that, the linkage between infrastructure and economic growth are varied and complex." Infrastructure does not only affect production and consumption directly, but determines growth [20] Stern (1991), it also create many direct and indirect externalities [22] Sekaran (2013)

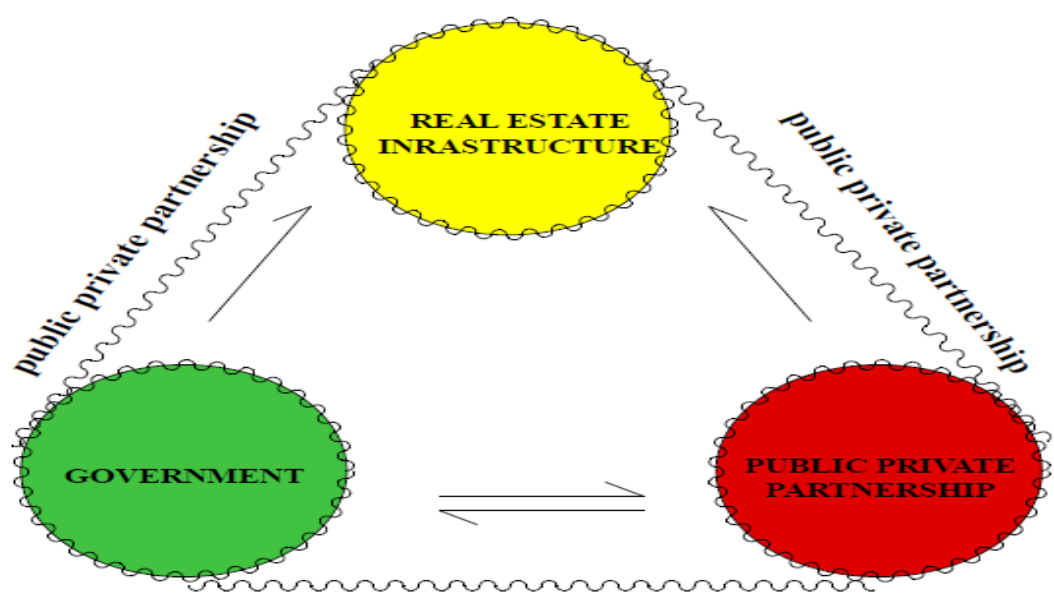

public private partnership

Figure 1: A FLOW DIAGRAM OF REAL ESTATE INFRASTRUCTURE

The diagram above illustrates how public private partnership functions, it's also explains the relationship between government and private partnership towards providing real estate infrastructure, the government can provide real estate infrastructure independently while private and public can provide some real estate infrastructure under partnership with the government.

[23] Adebayo (2012) stated that one of the determinants of the property values is infrastructural facilities, which has its own characteristics [24] Ominrin (2004), the preserve of which leads to appreciation of property values and its absence affect neighborhood prices adversely. Infrastructure 


\section{International Journal of Engineering Applied Sciences and Technology, 2020 \\ Vol. 4, Issue 11, ISSN No. 2455-2143, Pages 28-33 \\ Published Online March 2020 in IJEAST (http://www.ijeast.com)}

development is a key driver of increased productivity and economic growth hence leading to improve living standards, poverty reduction and attainment of the sustainable development goals (SDGs).

Infrastructure is a backbone of national development, it serves as a fulcrum which propels every sector be it housing, banking, industrialization, agriculture, engineering etc.

Countries like Dubai, India, China etc. are now referred to as second world countries just because the gross level of their national infrastructure propels all the sectors of their economy thereby making them the best among their counterpart countries of the world.

\section{CLASSIFICATION OF REAL INFRASTRUCTURE}

Classifications of Infrastructure are as follows:

i. Security infrastructure [25] Kyle Dees and Syed (2014) and [ 26] Singh(2001)

ii. Physical infrastructure [27] Emenike and Ezeudu (2018),[28] Olujimi and Bello (2009)

iii. Social infrastructure [29] Okafor (2016) [30] Bello and Arowosegbe (2014)

iv. Economic infrastructure

Afeikena(2015) [32] Salisu (2016)

v. Point and network infrastructure [33]James and Murungi (2015) [34] Jimoh (2017)

vi. Legal infrastructure [35] Anthony (2004)[36] Daniel (2007

Table 1 below provides a descriptive statistics of frequency, percent, valid percent of basic real estate infrastructural challenges facing the study area

Table 1: What are basic REI challenges Facing awka state

\begin{tabular}{|ll|l|l|l|l|}
\hline & & & & Cumulative \\
& & Frequency & Percent & Valid Percent & Percent \\
\hline Valid & Road network & 5 & 12.5 & 12.5 & 12.5 \\
& security & 28 & 70.0 & 70.0 & 82.5 \\
& power & 7 & 17.5 & 17.5 & 100.0 \\
Total & 40 & 100.0 & 100.0 & \\
\hline
\end{tabular}

The present study obtained data from both primary and secondary sources. The first step employed was a site visit and survey with relevant stake holders in a selected neighborhood like registered estate surveyor and valuer, land- lord associations, infrastructure companies at their various services, and tenants in the study area. From there our primary data was obtained. Again, the research team was made up of five trained and experienced research assistant and the researcher, using semi- structured questionnaire. The second step adopted in data collection, relevant data were also retrieved from newsletters, magazine, reputable journal, text books and websites.

A total of 75 questionnaires were distributed to releva nt stakeholders, $15(20 \%)$ registered estate surveyors a nd valuers, infrastructure companies 15 (20\%), landlord $20(27 \%)$ and tenant $25(33 \%)$ only $40(57 \%)$ was returned computed and analyzed.

Data where analyzed using Microsoft Excel, SPSS IBM software respectively, as the data were presented in tables while percentages, arithmetic mean, correlation, pearson " $\mathrm{r}$ " and relative importance index were used to determine the level of significance of the factors.

\section{RESULT AND DISCUSSION}




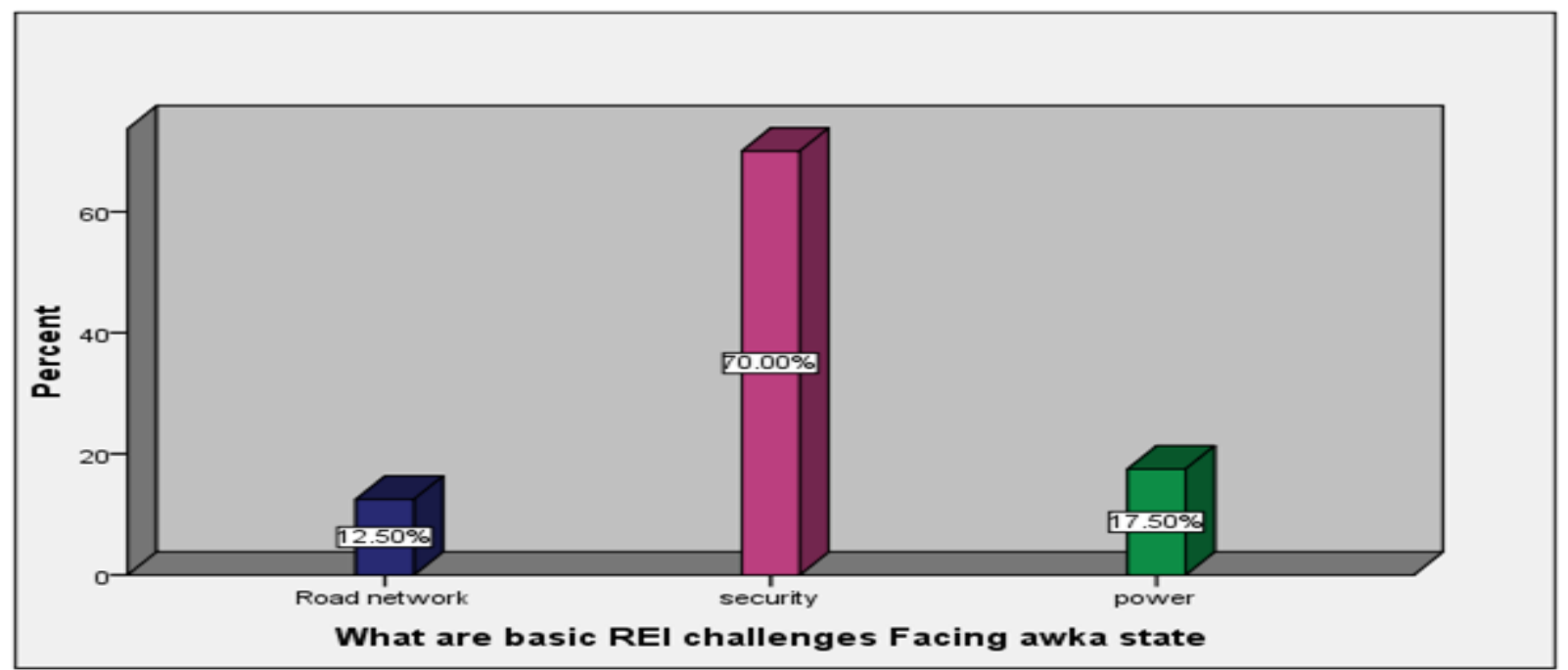

Figure 2:

Table 1, and figure 1 shows that from the three basic REI which comprises of road network, security and power in which other REI depends on its availability, the valid percentage (70.0) suggest that security was a major challenge facing the study area, the difference between security and road network $(82.14 \%)$, (power $75 \%$ ) indicates security has a higher role to play in preservation of other REI.

The study also discovered that poor government responds to public private partnership and attitude of private investor's response level are significantly related with assym. Sig 0.48 , secondly, the study revealed that the level of variance in respect to how $\mathrm{REI}$ is financed is dependent on the government $\mathrm{VS}=$
0.541. This is the highest value from the table. Thirdly, we also discovered that provision of real estate infrastructure (REI) is dependent on government $(45 \%)$ and individual $(35 \%)$ leaving public private partnership with $(20 \%)$, the reason for this, the practice of (PPP) has not gained it position as an alternative for providing real estate infrastructure consequently, from the analysis symmetric measures show value of significance to $\mathrm{R}=0.498$ which means, implementation PPP is very reliable with variance statistics of VS $=0.513$. finally the study also revealed that REI is majorly financed by the government, which has also been the reason for infrastructural deficit in the study area as illustrated in figure 2.
Who fin ances REI in awka state

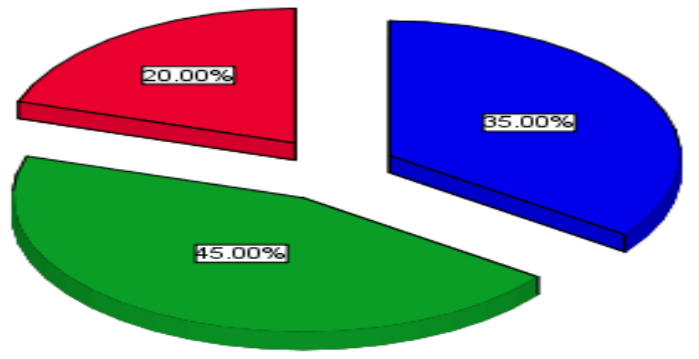

Figure 3

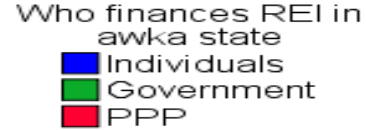

Government 


\section{International Journal of Engineering Applied Sciences and Technology, 2020 \\ Vol. 4, Issue 11, ISSN No. 2455-2143, Pages 28-33 \\ Published Online March 2020 in IJEAST (http://www.ijeast.com)}

\section{CONCLUSION}

The primary aim of this paper was to systematically ascertain best alternatives measures in providing real estate infrastructure and at the same time evaluate its impact on our national economy. On the basis of our findings as reviewed and analyzed we recommend that private investors should partner with the relevant stake holders in the real estate sector as government provides an enabling environment through encouraging (PPP) and fiscal policies that will rejuvenate REI industry. The end point will create opportunity at different levels and new level of developmental change. Attaching some benefit, exemptions, and adequate review of policies and implementation strategy will give the industry a photosynthetic reaction with maximum efficiency to improve our property market, capital per income of real estate investors, and sustainable environment that will attract investors. Depending on government is a good approach but, the demerits in respect to procedure, legislation, and duration lingers development, on the other hand sourcing REI from individual is capital intensive, private public partnership (PPP) is an alternative to achieve this goal without going through much challenges. The adaptation of this method if properly harnessed planed and managed effectively will transform our national economy from the grass root in a pleasant manner through economic enhancement, environmental sustainability and security stability.

Acknowledgements

I wish to acknowledge the contributions of everyone, especially authors and publishers, whose works were consulted during the execution of this study and others who contributed directly or indirectly to the success of this work.

I sincerely want to acknowledge the roles of professor Godfrey Okon Udo and Dr.Francis P. Udo (both of the university of Uyo) in the course of writing my master of science dissertation which this study is part of.

\section{REFRENCE}

[1] Ozigbo, I. and Ozigbo, C.A (2013).Professionalization of our Facility Management Function as the Basic for the Optimization of Public Infrastructure in Nigeria. Journal of the Nigeria Institution of Estate Surveyor and Valuers (JNIESV) Vol.3 no. 38/ (pp.21-2).
[2] Iloaba Judge(2009). Property Development II Mimeograph Department of Estate Management Federal Polytechnic Oko. (pg. 17-30).

[3] Stapleton, T. (1986). "Estate Management Practice", $2^{\text {nd }}$ Edition, the Eastern Gazette Ltd, London.(pp.47-51)

[4] thorncroft, M. (1965).Principles of Estate Management, the Estate Gazette, London.

[5] Igbinosa, S.O. (2011). Determinants of Residential property Value in Nigeria a Neural Network Approach

[6] Joslin, A. (2005).An Investigation into the Expression of Uncertainty in Property Valuation. Journal of Property Investment and Finance Vol. 23 no. 3, (pp.269-285).

[7] Kauko, T. (2003).Residential Property Value and Locational Externalities-on the Complementarity and Substitutability of Approaches. Journal of Property Investment and Finance Vol. 21, no. 3, (pp.250-270).

[8] Olusegun, G.K. (2003). Principles and Practice of Property Valuation (Volume One: General Principles). Climax Communications Limited, Lagos [9] Onyebanji, A.O (2003). Principles of Land Use Economics Center for Environmental Planning Development and Management, Lagos page (pp.5362).

[10] PUNCH, (2013). Magodo Residents urge Lagos to Construct Roads. A Publication of the Punch Newspaper April 5 Retrieved From http://www.punchng.com/magodo-residents-urge-

lagos-to-construct-roads/

[11] Karol, K. (2010).Determinants of Real Estate Investment, Journal of Economic and Sociology, Vol.3, No2.

[12] Board, E.S.R. (2016).Vulnerabilities in the EU R esidential real Estate Sector. [Online] Available

https://ersb.europa.eu/pub/ pdf/Reports/161128 Vulnerabilities EU Residential Real Estate Sector.en.pdf

[13] Golob, K., Bastic, M., and Psunder, I.(2012). Analysis of Impact Factors on the Real Estate Market: Case Slovenia.Inzinerine EkonomikaEngineering Economics, 23(4),357-37. http://doi.org/10.5755/jo1.ee.23.4.2566

[14] Dadem, Y.Y.D. (2009).Property Law Practice in Nigeria, Jos; University of Jos.

[15] Drummond, W.F. (1955). Social Justice. U.S.A: the Bruce Publishing Company.

[16] Ariyawansa R.G (2009). Principle of Real Estate Development and Management: University of Sri Jayewardenepura, Sri Lanka (pp.67-80).

[17] Udechukwu, C.E., and Olusola, J. (2008). Principle of Valuation Treem Nigeria Ltd Lagos (pg18-20). 


\section{International Journal of Engineering Applied Sciences and Technology, 2020 \\ Vol. 4, Issue 11, ISSN No. 2455-2143, Pages 28-33 \\ Published Online March 2020 in IJEAST (http://www.ijeast.com)}

[18] Scarret, D. (1995), Property Asset Management, E \& FN SPON,London.(pp.37-41).

[19] Francs U. and Beulah O. (2017). Development O f Physical Infrastructure A Midest Comatose Legal Framework In Urban Nigeria. Journal Of Urban Sustainable Studies (pp.9-11)

[20] Stern, N. (1991). The Determinants of Growth.Economic Journal, 101(404) (pp.122-133).

[21] Ajibola M.O. (2013).Effect Of Infrastructure On Property Values In Unity Estate Lagos. International Journal Of Economy, Management, And Social Sciences.2(5), (pp.195-201).

[22] Sekaran, D. (2013) The Impact of Public and Private Sector Transparency on Foreign Direct Investment in Developing Countries. Critical Perspective on International Business, 5(3),(pp.18720).

[23] Adebayo M.A (2012). The State of Urban Infrastructure And It Effect In Property Value In Lagos State Nigeria. Journal of Land Use and Development Studies .2(1), (pp.108-122).

[24] Ominrin MM (2004).Guideline for the Effective Management of Public Infrastructure in Nigeria.The Estate Surveyor and Valuers. Vol. 22 no1( pp.15-21). [25] Kyle Dees, M.S. and Syed, S.R (2011).Enhancing Infrastructure Security in Real Estate. International Journal of Network Security and its Applications (IJNSA), Vol. 3, No. 6, November.

[26] Singh, K. (2001). IT Infrastructure Security-

Step by Step. Retrieved on January 31,2011 from

http://www.sans.org/reading_room/whitepapers/basic infrastructure-security-step-step_430.

[27] Emenike, K.C.and Ezeudu, C.U.(2018). Commercialization of Real Estate Infrastructure as a tool for sustainable economic development in Nigerian dwindling economy (a case study Awka capital) Pristine Journal of Assertiveness, Vol.13, No1, November, 2018: ISSN 227-9684(pp.181-191). https://globalacademicgroup.com

[28] Olujimi, J.A.B. and Bello, M.O (2009).Effects of Infrastructural Facilities on Rental Values of Residential Properties.Social Science, 5(4), (pp.332341).

[29] Okafor, B.N (2016). The Residential housing Problem in Anambra State (a Case Study of Ontisha Metropolis). International Journal of Civil Engineering, Construction and Estate Management,Vol.4, No.2, (pp.22-39) May. https://www.eajournals.org

[30] Bello, I..K and Arowosegbe O.S (2014). Factors Affecting Land-Use Change on Property Values in Nigeria. Journal of Research in Economics and International Finance (JREIF) (ISSN:2315671) Vol.3, (4)(pp.79-82).
[31] Afeikhena, J.(2015). Infrastructure, Economic Growth and Poverty Reduction in Africa (pp.43-103) in Anam, B and Antai, A.S. (eds) Infrastructure, Economic Growth and Poverty Reduction in Africa, Nigeria: Ethereal Bliss

[32] Salisu, A.K (2016). Socio-Economic Infrastructure and Development: an Analytical Assessment from Nigerian Perspective. Journal of Humanities and Social Science (IOSR-JHSS) vol. 21, Issue 10(4) ISSN: 2279-0845

(PP.36-42).

[33] James, M.G. and Murungi, .M (2015).Infrastructure Development and Real Estate Values in Meru County, Kenya. Research Journal of Finance and Accounting. ISSN: 2222-1697, Vol.6, No.8, (pp. 212-221).

[34] Jimoh, D.A. (2017) Public Infrastructure vs. Residential Property Rental Value in Lagos, Nigeria. Journal of Sustainable Development Studies. ISSN: 2201-4268 Vol. 10, No.1, (pp.17-33).

[35] Anthony, O. (2004).The Importance of Legal Infrastructure for Regulation (and Deregulation) in Developing Countries. Conference paper Delivered at CRC Annual Conference, "Innovation and Change in Regulation and Completion" (pp.1-27).

[36] Daniel, M.K. (2007). Legal Infrastructure, Judicial Independence, and Economic Development, University of Pacific Press, U.S.A (pp.427-434). 